\title{
Immunological detection of AcAMP antimicrobial peptide secreted by Aspergillus clavatus
}

\author{
Ehsan Zamani' ${ }^{1}$, Jamil Zargan ${ }^{1}$, Hossein Honari' ${ }^{1}$ Abbas Hajizade ${ }^{1}$, Ashkan Haji Noor Mohammadi ${ }^{1}$, \\ Hani Keshavarz Alikhani ${ }^{2}$, Ahmad Heidari ${ }^{3}$, Mohammad Hossein Pour ${ }^{1}$ \\ ${ }^{I}$ Department of Biological Sciences, Faculty of Sciences, Imam Hossein University, Tehran, Iran \\ ${ }^{2}$ Department of Biology, Razi University, Kermanshah, Iran \\ ${ }^{3}$ Department of Agronomy and Plant Breeding, Faculty of Agriculture, University of Zanjan, Zanjan, Iran
}

Received: April 2020, Accepted: February 2021

\begin{abstract}
Background and Objectives: Aspergillus clavatus antimicrobial peptide (AcAMP) is a fungi-derived peptide with a broad spectrum of activity against pathogenic bacteria and fungi. Natural antimicrobial peptides, including AcAMP, have attracted many attentions in the development of new natural antibiotics against pathogenic bacteria, especially multidrug resistant ones.

Materials and Methods: In the present study, acamp gene was codon-optimized and chemically synthesized in pUC57 cloning vector, subcloned into pET28a (+) expression vector and transferred into competent Escherichia coli BL21 (DE3) cells. The expression of AcAMP was induced by addition of Isopropyl $\beta$ - d-1-thiogalactopyranoside (IPTG) and the expressed peptide was purified by Ni-NTA. BALB/c mice were immunized with the purified peptide and the ability of the immunized mice sera for the detection of the native AcAMP secreted by A. clavatus IRAN 142C was examined through ELISA and Western blotting techniques.

Results: Both ELISA and Western blotting demonstrated the ability of the sera of the immunized mice to detect the native AcAMP.

Conclusion: The results of the present work show that the raised antibody against recombinant AcAMP can be used to detect AcAMP peptide, an issue which paves the way to develop detection kits for the detection of AcAMP-producing organisms, purification of this valuable peptide for further investigations.
\end{abstract}

Keywords: Fungi; Aspergillus; Antimicrobial peptides; Recombinant proteins; Enzyme-linked immunosorbent assay

\section{INTRODUCTION}

Emerging of multidrug resistance bacteria has sounded the alarm for the need for developing new antimicrobial drugs (1). In recent years, finding new

"Corresponding author: Jamil Zargan, Ph.D, Department of Biological Sciences, Faculty of Sciences, Imam Hossein University, Tehran, Iran.

Tel: +98-912-6797530

Fax: +98-2177104935

Email: jazrgan@ihu.ac.ir antibiotics with biological origin which can be used in medicine has been an active area of research (2). Natural antimicrobial peptides are promising compounds in this regard. These peptides typically have small sizes, thermostable structures, wide range of antimicrobial activities and low immunogenicity (3). Filamentous fungi are a major source of antimicrobial peptides and proteins (4) and there have been many investigations on these peptides(2, 5-10). Anti-fungal protein (AFP), which is purified from Aspergillus giganteus, and Penicillium anti-fungal protein (PAF), which is purified from Penicillium chrysogenum,

Copyright $\odot 2021$ The Authors. Published by Tehran University of Medical Sciences. 
are two major antimicrobial peptides that the latter is investigated for the treatment of invasive pulmonary aspergillosis in animal model (11) and dealing with pests in transgenic plants (12), respectively. A. clavatus antimicrobial peptide (AcAMP) is a $6 \mathrm{kDa}$ cysteine-rich basic peptide purified from A. clavatus ES1 whose biochemical properties was characterized in 2010 (6). The unique properties of AcAMP, such as thermostability and wide range of antimicrobial activity (including toxicity against Escherichia coli) indicated that this peptide is a good potential candidate to cope with microbial resistance.

Finding the natural sources of these peptides is an important step to extract and use them in desired applications. Polyclonal antibodies are easy-to-prepare compounds which can be exploited in different immunological-based detection techniques, such as ELISA and immunoblotting (13). In this study, the acamp gene was cloned in pET28a expression vector. AcAMP was purified and used for the immunization of mice in order to produce polyclonal antibody. The ability of the produced antibodies for the detection of native AcAMP, obtained from A. clavatus, was also evaluated using ELISA and Western blotting.

\section{MATERIALS AND METHODS}

Microbial strains and plasmids. A. clavatus IRAN142C, as the potential producer strain for production of AcAMP peptide, was prepared from Iranian Research Institute of Plant Protection, Tehran, Iran (IRIPP). E. coli BL21 (DE3) (Invitrogen), as the host for recombinant production of the peptide, was prepared from Biology Research Center, Imam Hossein University. pUC57 cloning vector containing acamp gene was purchased from Sina Clon, Tehran, Iran.

Design and construction of the recombinant pET28a expression vector. The sequence of acamp gene was adopted from the NCBI GeneBank data- base with the accession number of GU390689.1. The sequence was codon-optimized according to the desired expression host (E. coli BL21 (DE3)) (Table 1). After codon optimization, the sequence was chemically synthesized in pUC57 cloning vector by SinaClone Co. (Tehran, Iran) between BamHI (5' end), SalI (3' end) restriction sites. Plasmid extraction was performed from the transformed cells using plasmid extraction kit (Bioneer, Korea). To amplify the acamp gene sequence for subsequent cloning of the gene into pET28a (+) expression vector, suitable primers were designed using Oligo 7 software, which sequences are shown in Table 2.

For the construction of pET28a-acamp, firstly, the gene was amplified by PCR reaction $\left(1\right.$ cycle of $95^{\circ} \mathrm{C}$ for $5 \mathrm{~min} ; 30$ cycles of $95^{\circ} \mathrm{C}$ for $30 \mathrm{~s}, 54^{\circ} \mathrm{C}$ for $30 \mathrm{~s}$, $72^{\circ} \mathrm{C}$ for $40 \mathrm{~s}$; and a final cycle of $5 \mathrm{~min}$ at $72^{\circ} \mathrm{C}$ in a Biorad thermocycler, C1000, Hercules, California, USA). Then, the PCR products were double digested with BamHI and SalI restriction enzymes (ThermoFisher Scientific, USA) and ligated into pET-28a vector digested with the same enzymes using T4 DNA ligase (ThermoFisher Scientific, USA). The recombinant vector was transferred into E. coli BL21 (DE3) strain as the expression host. Transformed bacteria were screened by LB medium (Roche, Germany) supplemented with kanamycin at a final concentration of $80 \mu \mathrm{g} / \mathrm{ml}$ (Sigma, USA) (14). The transformed bacteria were confirmed by PCR (using universal pET28a primers) and gene sequencing methods.

Expression and purification of recombinant peptide using IMAC chromatography. To express

Table 2. The sequence of the designed primers for amplification of acamp gene.

\begin{tabular}{llcc}
\hline $\begin{array}{l}\text { Primer } \\
\text { type }\end{array}$ & Sequence & $\begin{array}{c}\text { Nucleotide } \\
\text { number }\end{array}$ & $\begin{array}{l}\text { Tm } \\
\left(\mathbf{C}^{\circ}\right)\end{array}$ \\
\hline Forward & ACCTCGCGAATGCATCTAG & 19 & 56.5 \\
Reverse & ATTACGCCAAGCTTGCATG & 19 & 56.1 \\
\hline
\end{tabular}

Table 1. The sequences of the optimized gene and the expressed peptide

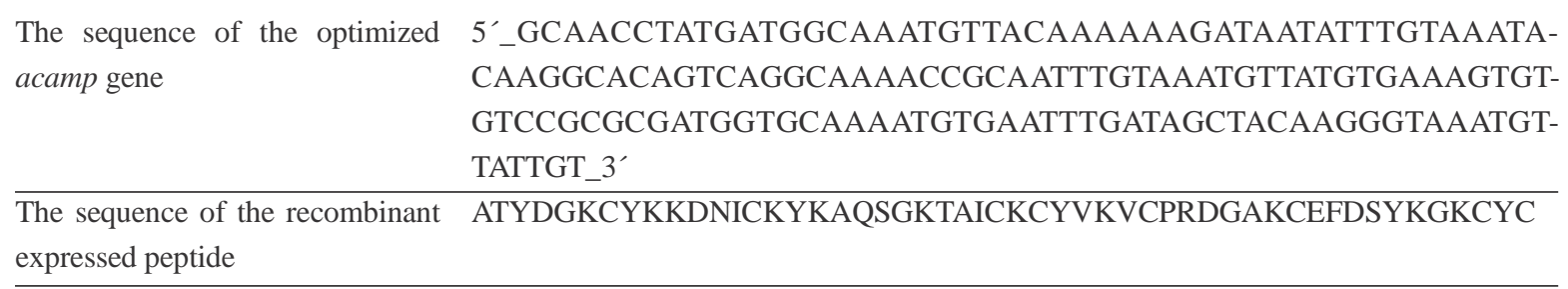


recombinant AcAMP, first of all, the overnight cultured bacteria were subcultured in LB medium (Roche, Germany) supplemented with kanamycin at a final concentration of $50 \mu \mathrm{g} / \mathrm{ml}$ (Sigma, USA) in a shaker incubator $\left(150 \mathrm{rpm}\right.$ shaking at $\left.37^{\circ} \mathrm{C}\right)$ until the OD $(600 \mathrm{~nm})$ reached 0.8 . Then, the expression of AcAMP was induced by addition of IPTG (isopropyl-1-thio-ß-D-galactopyranoside) at a final concentration of $1 \mathrm{mM}$ (Roche, Germany) and incubation for 4 hours at $37^{\circ} \mathrm{C}$. Next, the bacterial cells $(3 \mathrm{ml})$ were centrifuged at $5000 \mathrm{rpm}$ for $5 \mathrm{~min}$. The supernatant was discarded and the pellet $(\sim 1 \mathrm{mg})$ was suspended in $150 \mu \mathrm{l}$ of PBS buffer $(137 \mathrm{mM} \mathrm{NaCl}, 2.7 \mathrm{mM} \mathrm{KCl}$, $10 \mathrm{mM} \mathrm{Na} \mathrm{HPO}_{4} \cdot 12 \mathrm{H}_{2} \mathrm{O}, 2 \mathrm{mM} \mathrm{KH} \mathrm{PO}_{4}$ ) at $4^{\circ} \mathrm{C}$; Then, the cells were lysed by sonication by a sonicator (UP-200S Dr. Hielscher, Germany) (5 cycles of 15 seconds with amplitude of 75). The suspension was centrifuged at $14000 \mathrm{rpm}$ for $30 \mathrm{~min}$ at $4^{\circ} \mathrm{C}$ and the supernatant was stored at $-20^{\circ} \mathrm{C}$. The pellet was resuspended in $150 \mu$ l of lysis buffer $\left(100 \mathrm{mM} \mathrm{NaH}_{2} \mathrm{PO}_{4}, 10\right.$ $\mathrm{mM}$ Tris- $\mathrm{HCl}, 8 \mathrm{M}$ urea, and $\mathrm{pH} 8$ ) at $25^{\circ} \mathrm{C}$ for 1 hour and then centrifuged at $14000 \mathrm{rpm}$ for 30 minutes. The supernatant was stored at -20 for inclusion body formation analysis. $20 \mu \mathrm{l}$ of each sample was mixed with $5 \mu$ of $5 \times$ sample buffer and boiled at $100^{\circ} \mathrm{C}$ for 5 minutes. Finally, the samples were analyzed on a $15 \%$ sodium dodecyl sulfate-polyacrylamide gel electrophoresis (SDS-PAGE) under denaturing conditions as described by Bollag et al. (15).

To express and purify the recombinant peptide in large quantities, the transformed cells were grown in a $250 \mathrm{ml}$ Erlenmeyer flask. Protein purification was carried out by affinity chromatography (IMAC) using Ni-NTA under denaturing conditions (Qiagen, USA). Briefly, $50 \mathrm{ml}$ of the bacterial culture was centrifuged at $10,000 \mathrm{~g}$ for $5 \mathrm{~min}$. The supernatant was discarded and $3 \mathrm{ml}$ of the lysis buffer was added to the pellet. The pellet was completely dissolved in the lysis buffer by a gentle shaking at $37^{\circ} \mathrm{C}$ for $1 \mathrm{~h}$. Then, the mixture was centrifuged at $20,000 \mathrm{~g}$ for $30 \mathrm{~min}$ at $4^{\circ} \mathrm{C} .1 \mathrm{ml}$ of the supernatant was applied onto an Ni-NTA column containing $1 \mathrm{ml}$ of nickle resin. The flowthrough was collected and $1 \mathrm{ml}$ of buffer C $(100 \mathrm{mM} \mathrm{NaH} \mathrm{PO}$, $10 \mathrm{mM}$ Tris- $\mathrm{HCl}, 8 \mathrm{M}$ urea, $\mathrm{pH}$ 6.3) was applied to the column. The flowthrough was collected and the process was repeated by addition of $1 \mathrm{ml}$ of buffer D (100 mM NaH $2 \mathrm{PO}_{4}, 10 \mathrm{mM}$ Tris- $\mathrm{HCl}$, and $8 \mathrm{M}$ urea, $\mathrm{pH}$ 5.9) and $\mathrm{E}$ (100 mM NaH $\mathrm{PO}_{4}, 10 \mathrm{mM}$ Tris- $\mathrm{HCl}$, $8 \mathrm{M}$ urea, $\mathrm{pH} 4.5)$. Finally, the column was washed with $1 \mathrm{ml}$ of $250 \mathrm{mM}$ imidazole $(300 \mathrm{mM} \mathrm{NaCl}, 50$
$\mathrm{mM} \mathrm{Na} \mathrm{HPO}_{4}, 250 \mathrm{mM}$ imidazole, $\mathrm{pH} 8$ ) and $1 \mathrm{ml}$ of $20 \mathrm{mM}$ MES buffers. The collected fractions were analyzed on a $15 \%$ SDS-PAGE as noted above and the purified recombinant peptide concentration was determined by Bradford method with bovine serum albumin as the standard protein (15).

Immunization of mice to elicit antibody production. To produce polyclonal antibody against AcAMP peptide, five female mice (20-25 g) were immunized intraperitoneally using recombinant peptide followed by three boosts (days $0,14,28,42$ ).

In the first injection (day 0), $100 \mu \mathrm{l}$ of "VAX-ORIENT IPA-70" adjuvant (Pars Vaccine Technology, Iran) was homogenized with $20 \mu \mathrm{g}$ of recombinant peptide and mixed with PBS to a final volume of 200 $\mu 1$. Similarly, in the next boosts (days 14, 28, 42), 20 $\mu \mathrm{g}$ of recombinant peptide homogenized with the mentioned adjuvant and were intraperitoneally injected to the animals (Table 3) $(16,17)$. Finally, we used prepared serum sample on day 49 due to its maximum antibody titer for the subsequent studies (Fig. 3). All experiments were executed according to the Guide for the Care and Use of Laboratory Animals and were approved by the institutional animal ethics committee.

Fungal culture and peptide production. A. clavatus IRAN142C was exploited for the production of AcAMP peptide. The fungus was cultured as the method described by Hajji et al. with some modifications (6). Briefly, $50 \times 10^{7}$ spores of the fungus was inoculated into $50 \mathrm{ml}$ culture medium $(0.5 \%$ yeast extract, $1 \%$ peptone and $0.5 \% \mathrm{NaCl}$ supplemented with $2 \%$ glycerol) and incubated in a shaker incubator $\left(150 \mathrm{rpm}\right.$ at $30^{\circ} \mathrm{C}$ for $96 \mathrm{~h}$ ). The culture was filtered through four layers of cheese cloth and centrifuged at $8000 \mathrm{rpm}$ for $20 \mathrm{~min}$. The supernatant, which contained the AcAMP peptide, was further concentrated by Amicon centrifugal ultrafiltration (MW cut-off; 3.000, Millipore, USA) (6). The concentration of the obtained crude protein was determined by the Bradford method (15) and the protein was stored at -20 for subsequent studies.

Immunological detection of the peptide: ELISA. To investigate the ability of the raised antibodies against the recombinant AcAMP and to detect the fungus-produced non denatured AcAMP, indirect ELISA was used $(16,17)$. For this aim, a flat-bottom 96-well plate was coated with serial- 
Table 3. Time table for mice administration.

\begin{tabular}{lccc}
\hline Administration Schedule & Day & $\begin{array}{c}\text { Concentration of the } \\
\text { Administered Antigen }(\boldsymbol{\mu g} / \mathbf{m i c e})\end{array}$ & Adjuvant \\
\hline First administration & 1 & $20 \mu \mathrm{g}$ & VAX-ORIENT IPA-70 \\
Second administration & 14 & $20 \mu \mathrm{g}$ & VAX-ORIENT IPA-70 \\
Third administration & 28 & $20 \mu \mathrm{g}$ & VAX-ORIENT IPA-70 \\
Fourth administration & 42 & $20 \mu \mathrm{g}$ & VAX-ORIENT IPA-70 \\
\hline
\end{tabular}

ly diluted crude protein starting at $10 \mu \mathrm{g}$ in $100 \mu \mathrm{l}$ coating buffer (15 mM Na CO, $36 \mathrm{mM} \mathrm{NaHCO}$, $\mathrm{pH}$ 9.8) and incubated at $4^{\circ} \mathrm{C}$ overnight. Then, the plate was washed with PBST (PBS containing 0.1\% (v/v) Tween 20). The wells were blocked with addition of $100 \mu \mathrm{l}$ of PBST containing 5\% skim milk and slight shaking at $37^{\circ} \mathrm{C}$ for $1 \mathrm{~h}$. After washing the wells, $100 \mu \mathrm{l}$ of 1:100 diluted mice serum samples in PBST was added to each well. The plate was incubated at $37^{\circ} \mathrm{C}$ for $30 \mathrm{~min}$ and washed again. Peroxidase anti-mouse IgG antibody (Amersham, UK, $1: 10000 ; 100 \mu 1 /$ well) was added to each well and the plate was incubated at $37^{\circ} \mathrm{C}$ for $30 \mathrm{~min}$. Then, the wells were washed and $100 \mu \mathrm{l}$ of the coloring buffer (3 mg of ortho-phenylenediamine (Sigma, USA) and $3 \mu \mathrm{l}$ of $\mathrm{H} \mathrm{O}$ in $5 \mathrm{ml}$ citrate buffer) was added to each well. Finally, the reaction was stopped with $2.5 \mathrm{M}$ $\mathrm{H}_{2} \mathrm{SO}_{4}(100 \mu \mathrm{l} /$ wells). The optical density was read with a microplate ELISA reader (Biotech 110, USA) at $492 \mathrm{~nm}$.

Western blotting. Western blot analysis was exploited to detect denatured form of the peptide. The prepared crude protein was transferred from a $15 \%$ SDS-PAGE onto a PVDF membrane (membrane solutions, USA) using a Bio-Rad Protean II system (BioRad, USA) and transferring buffer (192 mM glycine, $25 \mathrm{mM}$ Tris-base, $20 \%$ methanol and $\mathrm{pH}$ 8.3). To block the membrane, it was incubated in PBST containing 5\% skim milk / as blocking buffer for 16 at $4^{\circ} \mathrm{C}$.

After that, the blocking buffer was discarded and the membrane soaked in 1:1000 diluted mice serum samples in PBST with gentle shaking for $1 \mathrm{~h}$ at room temperature. Moreover, the membrane was submerged in 1:3,000 dilution of HRP-conjugated anti-mouse $\mathrm{IgG}$ and incubated for $1 \mathrm{~h}$ at room temperature with gentle shaking. Finally, the HRP staining solution, DAB (diamino benzidine) was used as revelation compound and the chromogenic reaction was stopped by rinsing the membrane in distilled water (15).

Statistical analysis. Data distribution normality was evaluated by Two-sample Kolmogorov-Smirnov test and the statistical significance between immunized mice serums and control was determined by paired Mann-Whitney test as non-parametrical data. Significance was defined at the $P<0.05$ level. Statistical analysis were performed by free statistical software R version 3.4.1 (18) run within the R Studio version 1.1.423 interface. All experiments were conducted in two replicates.

\section{RESULTS}

Construction of the recombinant vector. The acamp gene was inserted into pET 28a (+) expression vector. Fig. 1 schematically illustrates the steps of this process. The gene was amplified from pUC57 vector by PCR and double digested by restriction enzymes. The results were evaluated on a $2 \%$ agarose gel.

It should be mentioned that the cloning confirmation was carried out by PCR using universal pET28a $(+)$ primers and also gene sequencing.

Recombinant peptide expression. Peptide expression and the state of the expressed peptide in term of solubility was analyzed by using SDS-PAGE. As it can be seen in Fig. 2, almost all recombinant peptides have been expressed as inclusion bodies (The sequence of the optimized gene and its expressed peptide has been shown in Table 1).

Purification of recombinant peptide using affinity chromatography. The $9-\mathrm{kDa}$ recombinant peptide purification was carried out using NiNTA column chromatography. Briefly, after the introduction 


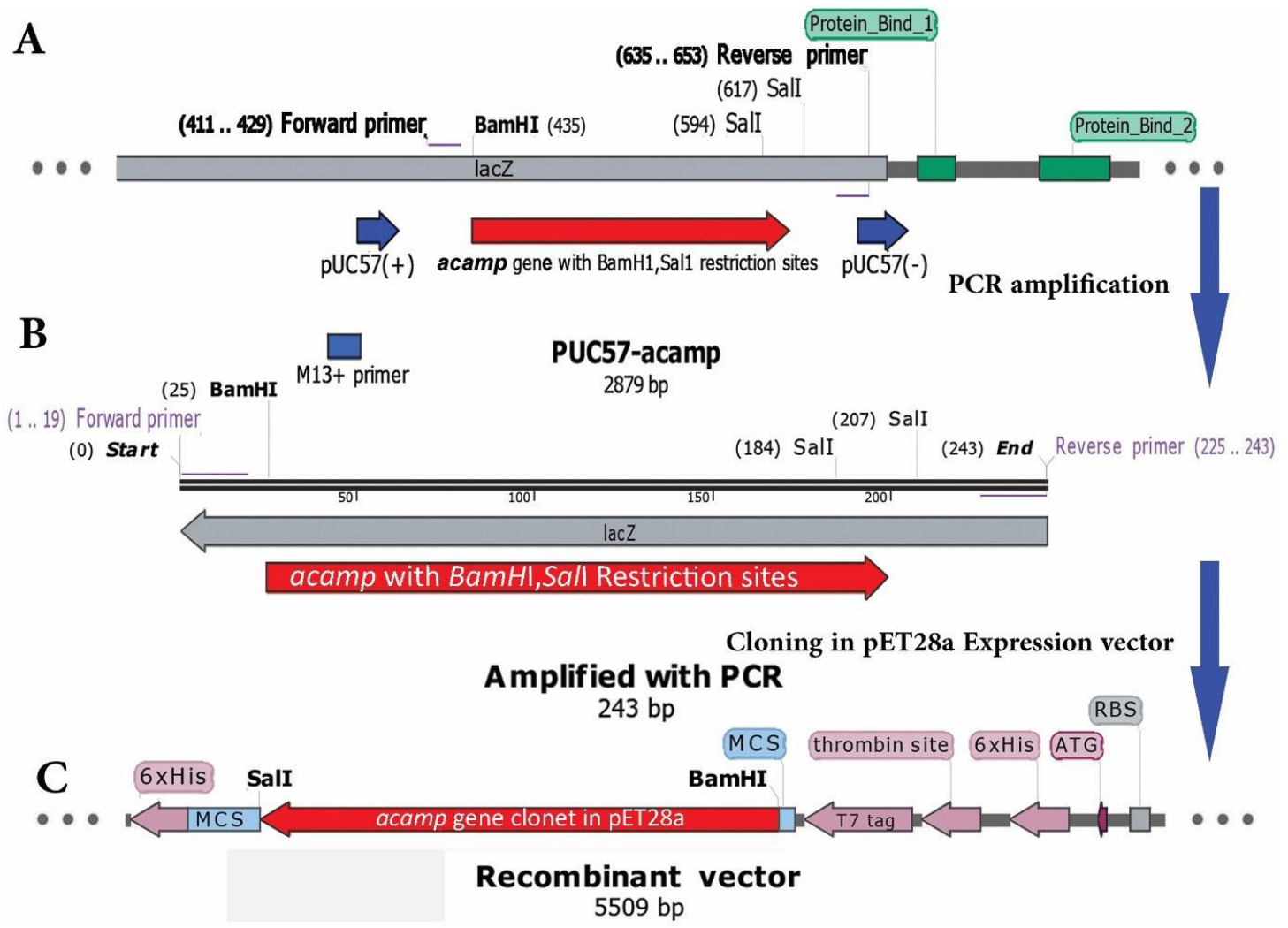

Fig. 1. Schematic process to amplify and cloning of acamp gene into pET28a

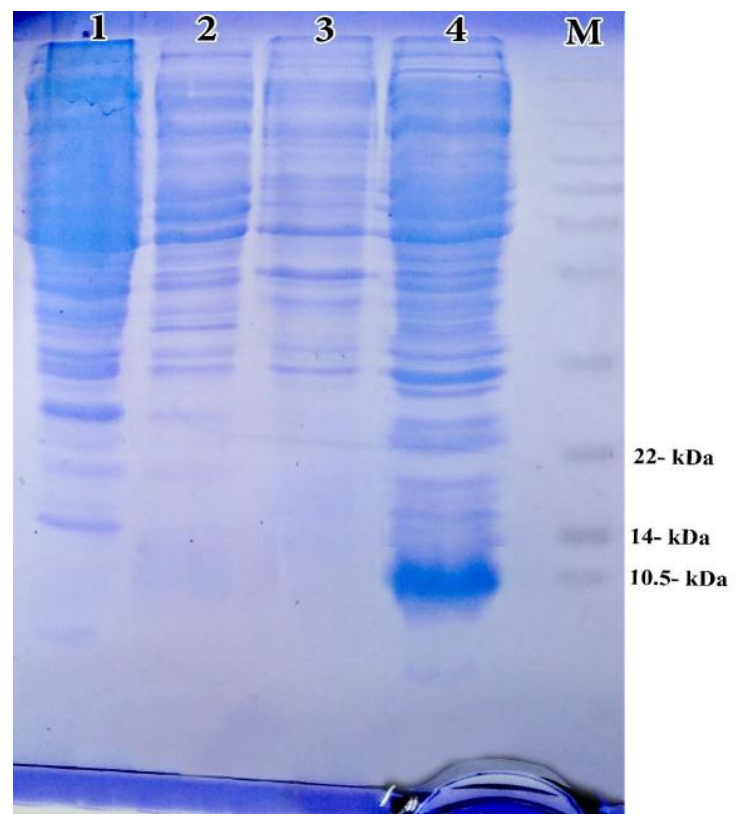

Fig. 2. Determination of the recombinant AcAMP solubility. Lane 1: Sonication of PBS-suspended un-induced cells. Lane 2: Sonication of PBS-suspended induced cells. Lane 3: Sonication of un-induced cells dissolved in $8 \mathrm{M}$ urea. Lane 4: Sonication of induced cells dissolved in $8 \mathrm{M}$ urea. M: Protein marker (Vivantis, Malaysia).

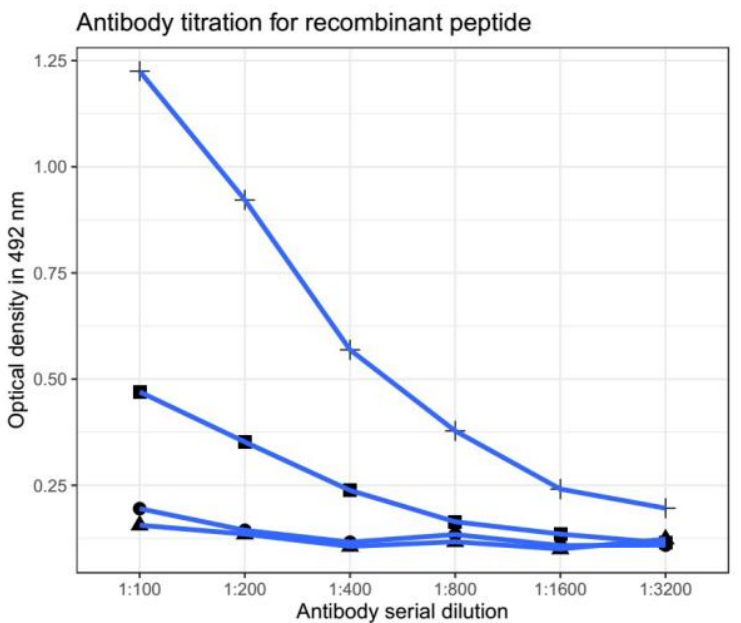

Fig. 3. Characterization of antibody production against recombinant AcAMP peptide in laboratory mice $(\bullet$ : Control sample $\mathbf{\Lambda}$ : First sampling $\mathbf{a}$ : Second sampling +: Third sampling).

of the crude protein onto the column, it was washed with incremental acidity tilt $(6.3,5.9$ and 4.5 , respectively) of $8 \mathrm{M}$ urea solutions. Finally, the column was washed with imidazole buffer. The majority of AcAMP peptide was dissociated from the column at $\mathrm{pH}$ 
Table 4. Recombinant peptide expression efficiency

\begin{tabular}{|c|c|c|c|}
\hline & $\begin{array}{l}\text { Crude } \\
\text { protein }\end{array}$ & $\begin{array}{c}\text { Elution } \\
\mathbf{E}\end{array}$ & $\begin{array}{c}\text { Elution } \\
\mathbf{I 2 5 0}\end{array}$ \\
\hline Amount $(\mu \mathrm{g} / \mathrm{ml})$ & 1225 & 270 & 159 \\
\hline Percentage purity of target peptide & 35 & 93 & $>98$ \\
\hline
\end{tabular}

value of 4.5. However, some of the peptide was still bounded to the resin and it was completely dissociated after addition of imidazole buffer in accordance with our previous report (19). It should be noted that the percentage of recombinant AcAMP within the total proteins was estimated as 35 percent (Table 4).

Production of native AcAMP by A. clavatus IRAN 142C. The production of the native peptide by A. clavatus IRAN $142 \mathrm{C}$ was analyzed on a $15 \%$ SDS-PAGE. The results indicated the presence of relatively high amount of the peptide band in the range of 6-kDa (Fig. 4A).

ELISA and Western blot analysis. We used indirect ELISA to characterize serum ability for non-denatured AcAMP detection, and also Western blot to detect the denatured form of AcAMP (20). The results showed that serum samples were not identical $(P$ value $=0.03125)$ and there is a significant difference between immune and control sera. As a result, it was found that the immune serum can detect the non-denatured form of AcAMP (Fig. 4B).

Investigation of the immune serum ability to detect the denatured form of the peptide by Western blotting showed the ability of the serum for the detection of the peptide (Fig. 4C).

\section{DISCUSSION}

In the present study, a fungal antimicrobial peptide, AcAMP, was recombinantly produced in $E$. coli expression system. The peptide was purified and administered to mice in order to obtain antibody against the peptide. The peptide was also produced by $A$. clavatus. The ability of the raised antibodies against the recombinant peptide to detect native AcAMP was investigated and shown that anti-recombinant AcAMP can efficiently detect both denatured and non-denatured forms of the native peptide.

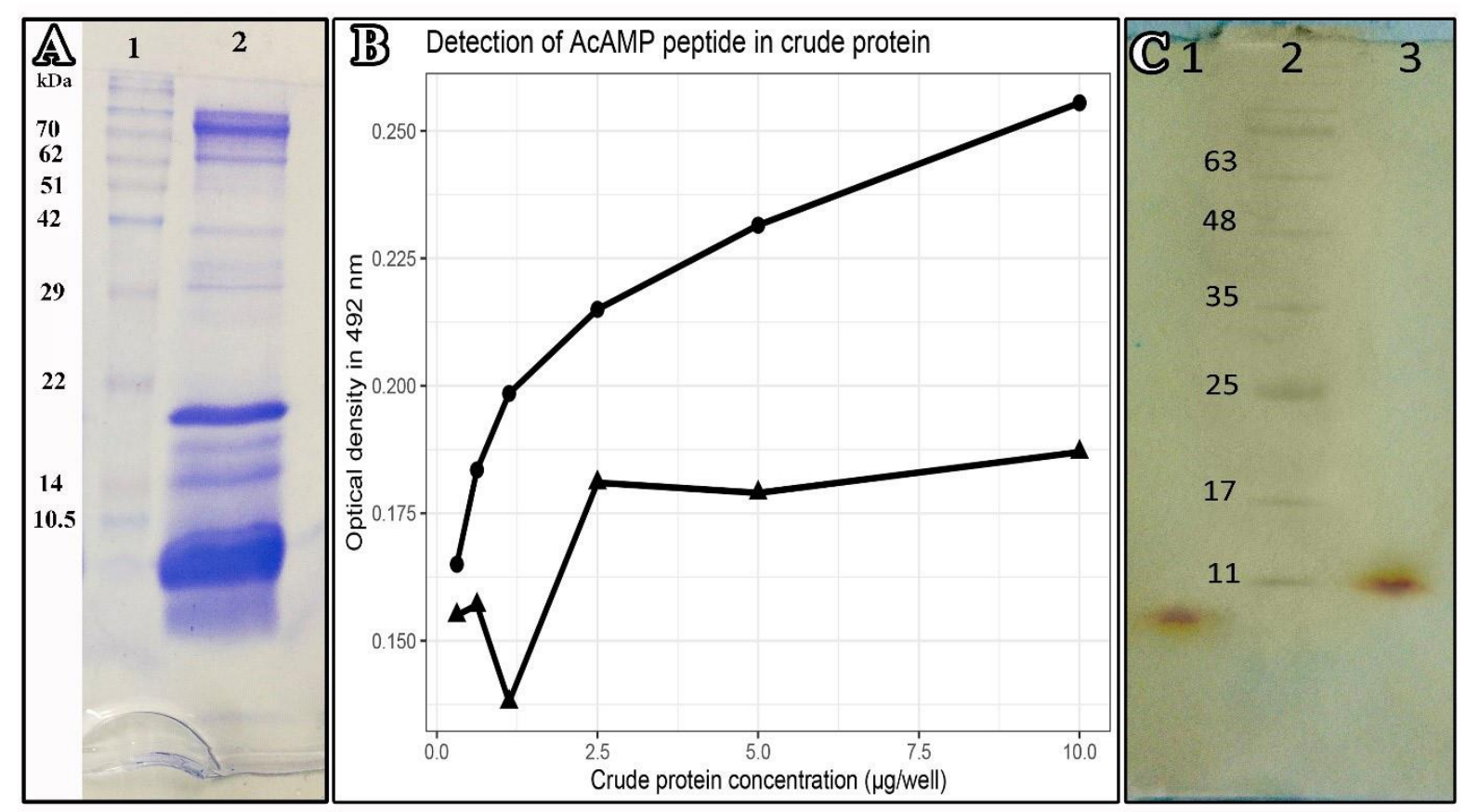

Fig. 4. Production and detection of AcAMP peptide. A) Protein production by A. clavatus IRAN 142C in LBG medium. Lane1: Protein marker (Vivantis, Malaysia). Lane 2: Proteins produced by the fungi. B) Detection of non-denatured form of AcAMP peptide in crude protein using indirect ELISA ( $\boldsymbol{\Lambda}$ : control serum, $\bullet$ : AcAMP serum). C) Western blotting to investigate the ability of the immune serum for the detection of denatured form of AcAMP. Lane1: Native AcAMP peptide in crude protein. Lane 2: Protein marker (Protein ladder PS10 Plus, GENEON, Germany). Lane 3: Recombinant AcAMP 
Recombinant production of biological products, including antimicrobial peptides and proteins, has been a proper strategy for large scale production of these compounds (21-23). In this study, pET28a (+) expression vector was exploited for recombinant production of AcAMP. Since the peptide has antibacterial activity on $E$. coli cells, codon usage of the acamp gene was altered in a way that maximum expression can achieve and, as a result, the expressed peptide form inclusion bodies. By this, the peptide is unable to exert its antibacterial activity and E. coli cells can continue peptide expression. At the experimental level, no detectable toxicity of the expressed peptide was observed on the host cells, which can be due to the inclusion body formation or extracellular exertion of antibacterial activity (3). Though the small peptides are not efficient in stimulating immunological response, however, intraperitoneal administration of the recombinant peptide using a potent adjuvant (VAX-ORIENT IPA-70) and also addition of a small tag (3-kDa) to the peptide was able to efficiently evoke humoral immunity of the mice. It has been shown that the administration route (20) as well as adjuvant type (24) has a great effect on the antibody production.

The ability of the raised antibodies against the recombinant AcAMP to detect the native peptide was investigated by two immunological techniques, ELISA and Western blotting. In ELISA, the peptide is present as the undenatured form. Both structural and linear epitopes can be detected by the raised antibodies in this situation. However, in Western blotting, since the protein is denatured, only linear epitopes can be recognized by antibodies. The results showed the raised antibodies were able to detect both undenatured and denatured forms of the peptide. The ability of the produced antibodies to detect the peptide in ELISA is a valuable finding which paves the way for its therapeutic and diagnostic applications.

Detection of the denatured form of AcAMP is another ability of the raised antibodies which suggest its application in different immunological-based methods, such as Western blotting and Immunohistochemistry (IHC) (25).

In conclusion, AcAMP peptide was expressed as recombinant peptide and used to produce polyclonal antibody. The produced antibody has relatively good efficiency to detect the denatured and undenatured form of the peptide, which pave the way for future studies.

\section{REFERENCES}

1. Li B, Webster TJ. Bacteria antibiotic resistance: New challenges and opportunities for implant-associated orthopedic infections. J Orthop Res 2018;36:22-32.

2. Skouri-Gargouri H, Gargouri A. First isolation of a novel thermostable antifungal peptide secreted by Aspergillus clavatus. Peptides 2008;29:1871-1877.

3. Mahlapuu M, Håkansson J, Ringstad L, Björn C. Antimicrobial peptides: an emerging category of therapeutic agents. Front Cell Infect Microbiol 2016;6:194.

4. Garrigues S, Gandía M, Popa C, Borics A, Marx F, Coca $\mathrm{M}$, et al. Efficient production and characterization of the novel and highly active antifungal protein AfpB from Penicillium digitatum. Sci Rep 2017;7:14663.

5. Galgóczy L, Virágh M, Kovács L, Tóth B, Papp T, Vágvölgyi C. Antifungal peptides homologous to the Penicillium chrysogenum antifungal protein (PAF) are widespread among Fusaria. Peptides 2013;39:131-137.

6. Hajji M, Jellouli K, Hmidet N, Balti R, Sellami-Kamoun A, Nasri M. A highly thermostable antimicrobial peptide from Aspergillus clavatus ES1: biochemical and molecular characterization. J Ind Microbiol Biotechnol 2010;37:805-813.

7. Geisen R. P. nalgiovense carries a gene which is homologous to the paf gene of $P$. chrysogenum which codes for an antifungal peptide. Int J Food Microbiol 2000;62:95-101.

8. Rodríguez-Martín A, Acosta R, Liddell S, Núñez F, Benito MJ, Asensio MA. Characterization of the novel antifungal protein PgAFP and the encoding gene of Penicillium chrysogenum. Peptides 2010;31:541-547.

9. Batta G, Barna T, Gaspari Z, Sandor S, Kövér KE, Binder U, et al. Functional aspects of the solution structure and dynamics of PAF-a highly-stable antifungal protein from Penicillium chrysogenum. FEBS $J$ 2009;276:2875-2890.

10. Kovács L, Virágh M, Takó M, Papp T, Vágvölgyi C, Galgóczy L. Isolation and characterization of Neosartorya fischeri antifungal protein (NFAP). Peptides 2011;32:1724-1731.

11. Palicz Z, Gáll T, Leiter É, Kollár S, Kovács I, Miszti-Blasius K, et al. Application of a low molecular weight antifungal protein from Penicillium chrysogenum (PAF) to treat pulmonary aspergillosis in mice. Emerg Microbes Infect 2016; 5(11): e114.

12. Coca M, Bortolotti C, Rufat M, Penas G, Eritja R, Tharreau D, et al. Transgenic rice plants expressing the antifungal AFP protein from Aspergillus giganteus show enhanced resistance to the rice blast fungus $\mathrm{Mag}$ naporthe grisea. Plant Mol Biol 2004;54:245-259.

13. Barrell PJ, Liew OW, Conner AJ. Expressing an antibacterial protein in bacteria for raising antibodies. Protein Expr Purif 2004;33:153-159. 
14. Joseph S, David WR (2001). Molecular cloning: a laboratory manual. Gold Spring Harbor, New York.

15. Bollag D, Rozycki M, Edelstein S (1996). Protein methods. 2nd eds. Viley-Liss Press, USA.

16. Jafari H, Jahromi ST, Zargan J, Zamani E, Ranjbar R, Honari H. Cloning and expression of N-CFTX-1 antigen from Chironex fleckeri in Escherichia coli and determination of immunogenicity in mice. Iran J Public Health 2021;50:376-383.

17. Mirhaj H, Honari H, Zamani E. Evaluation of immune response to recombinant Bacillus anthracis LFD1-PA4 chimeric protein. Iran J Vet Res 2019;20:112-119.

18. Team RC. R: A language and environment for statistical computing. R Foundation for Statistical Computing 2018.

19. Zamani E, Zargan J, Honari H. Cloning and expression of AcAMP Aspergillus clavatus in E. coli and investigate its antibody titration in mice. RJMS 2018;25:9-18.

20. Brown MC, Joaquim TR, Chambers R, Onisk DV, Yin F, Moriango JM, et al. Impact of immunization technology and assay application on antibody performance-a systematic comparative evaluation. PLoS
One 2011;6(12):e28718.

21. Jing X-L, Luo X-G, Tian W-J, Lv L-H, Jiang Y, Wang $\mathrm{N}$, et al. High-level expression of the antimicrobial peptide plectasin in Escherichia coli. Curr Microbiol 2010;61:197-202.

22. Ashcheulova DO, Efimova LV, Lushchyk AY, Yantsevich AV, Baikov AN, Pershina AG. Production of the recombinant antimicrobial peptide UBI18-35 in Escherichia coli. Protein Expr Purif 2018;143:38-44.

23. Meiyalaghan S, Latimer JM, Kralicek AV, Shaw ML, Lewis JG, Conner AJ, et al. Expression and purification of the antimicrobial peptide GSL1 in bacteria for raising antibodies. BMC Res Notes 2014;7:777.

24. Fogg CN, Americo JL, Lustig S, Huggins JW, Smith SK, Damon I, et al. Adjuvant-enhanced antibody responses to recombinant proteins correlates with protection of mice and monkeys to orthopoxvirus challenges. Vaccine 2007;25:2787-2799.

25. Forsström B, Axnäs BB, Rockberg J, Danielsson H, Bohlin A, Uhlen M. Dissecting antibodies with regards to linear and conformational epitopes. PLoS One 2015;10(3):e0121673. 